Rev. salud pública. 6 (2):156-166, 2004

Investigación/Research

\title{
Non-planed Urbanization as a contributing Factor for Malaria Incidence in Manaus-Amazonas, Brazil
}

\author{
Maria Jacirema Ferreira Gonçalves ${ }^{\mathrm{I}}$ Wilson Duarte Alecrim ${ }^{\mathrm{II}}$ \\ ${ }^{\mathrm{I}}$ Nurse. Master Science in Environmental Science. Universidade Federal do Amazo- \\ nas. Escola de Enfermagem de Manaus. Rua Teresina, 495 - Adrianópolis. CEP \\ 69057-070. Manaus-Amazonas-Brasil. E-Mail: mjacir@uol.com.br. \\ IIPhysician. Master Science in Tropical Medicine. Fundação de Medicina Tropical \\ do Amazonas. Centro Universitário Nilton Lins. Manaus-Amazonas-Brasil. \\ E-Mail:walecrim@uol.com.br
}

Recibido 26 Febrero 2004/Enviado para Modificación 28 Mayo 2004/Aceptado 4 Junio 2004

\begin{abstract}
Objectives This paper presents a study on the dynamics of malaria in Manaus and its relationship with the urban expansion and environmental factors related to it. The purpose of this paper is: to analyse how the form of occupying the emptied space in the city, together with the urbanization and factors related to the environment, have contributed for the establishment, increase and/or sustainability of malaria in the urban area of the city of Manaus, Amazonas, Brazil.

Methods A retrospective study was carried out on malaria epidemiology from 1986 to 1997; data on the evolution and urban expansion of the city of Manaus were surveyed. Data were descriptively analysed making a relationship between the environmental aspects of urbanization and the way the city of Manaus was occupied and how this has contributed to malaria epidemiology in the city.

Results The findings point out to the importance of the environment on malaria incidence, and to the influence of the anthropic interventions on the modification of the ecosystem, making the urban environment ideal for the proliferation of Anopheles $s p$ mosquitoes, vectors of this disease.
\end{abstract}


Conclusion These elements in association continue to favour the maintenance of the incidence of malaria in the urban area of Manaus.

Key Words: Malaria, environment, urbanization (source: $M e S H, N L M$ ).

\section{RESUMEN \\ Urbanización no planeada como factor que contribuye en la incidencia de malaria en Manaos-Amazonas, Brasil}

Objetivos Estudio de la dinámica de malaria en Manaos y su relación con la expansión urbana de la ciudad y los factores ambientales relacionados con la enfermedad. El objetivo es analizar como la forma de ocupación de la ciudad, la urbanización y factores relacionados al ambiente contribuyen en la instalación, aumento y/o manutención de la malaria en el área urbana de Manaus-Amazonas, Brasil.

Metodología Se realizó un estudio retrospectivo sobre la epidemiología de la malaria en el período de 1986 a 1997: levantamiento de datos sobre la evolución y expansión urbana de la ciudad de Manaus. Los datos fueron analizados descriptivamente, buscando relación con aspectos ambientales de la urbanización y la forma de crecimiento de la ciudad de Manaos, y cómo contribuyó en la epidemiología de la malaria en la ciudad.

Resultados Los resultados apuntan a la importancia que tiene el ambiente en el mantenimiento de la endemia de malaria, y también, la influencia de las intervenciones humanas en los cambios del ecosistema, dejando el ambiente urbano con las condiciones favorables para la proliferación del Anopheles, transmisor del parásito.

Conclusión La asociación de estos elementos favorecen el mantenimiento de la endemia de malaria en el área urbana de Manaos.

Palabras Claves: Malaria, ambiente, urbanización (fuente: DeCS, BIREME).

$\mathrm{M}$

alaria stands out as a major issue in the health care implementation activities, especially when considering the epidemiological factors, which are determinant for the establishment and maintenance of its transmission, namely the mosquito (Anopheles), the protozoa (Plasmodium) and the human being, its susceptible carrier.

From a biological viewpoint, malaria is well understood and simple, yet the established relations between mosquito, man and the environment make the characteristics, which determine the occurrence of a higher or lower number of sick people (1). Under this context, urbanization plays a major 
role, since the cities have become more urbanised, the Amazonian reality, have favored the ideal conditions for the increase of malaria cases.

When it is studied the environmental conditions who determine the malaria incidence in Manaus-Amazonas, Brazil, it can be noted that there is a strong relationship between the disease's incidence and the environmental urban expansion changes. This might provide means for future intervention and correction of the identified factors, as well as serve as a subsidy for the urban-environmental planning. Therefore, this research study aims to analyze the urbanization aspects that have an influence on the dynamics of malaria in the city of Manaus-Amazonas, Brazil, and its epidemiology in the period between 1986 and 1997.

\section{MATERIALS AND METHODS}

A retrospective study on the Manaus dynamics in Manaus-Amazonas, Brazil during the period of 1986-1997 (12 years), and a descriptive analysis making a relationship between the urbanization environmental aspects, the way the city has been occupied and how this contributed to the malaria epidemiology, were carried out, using:

- Epidemiological data about malaria incidence were obtained in the Brazilian National Health Foundation (FUNASA) and the Tropical Medicine Foundation of Amazonas (FMT/IMT-AM), from 1986 to 1997.

- The chronology of the urban evolution in Manaus, from 1665 to 1990, was collected in the Municipal Institute of Urban Planning of Manaus (IMPLAN).

- It was made interview with environmental institutions officials: the President of the Municipal Company of Urbanization (URBAM), who provided information related to the urban expansion; employees of the Secretariat Municipal of Works and Basic Sanitation (SEMOSB); and Real Estate matters Municipal General Office (SEMAF).

- Comparison of data relative to malaria per year, per city district and with the urban expansion; Collection and study of information on the infestation and re-infestation by the Anopheles darlingi in the city's centre-south zone and eastern districts;

- Comparison of those findings with the environmental changes resulting from urban expansion was done also. 
Statistical treatment was performed through the arrangement into spreadsheets, tabulation and interpretation of the information acquired. Data were plotted in tables and graphs according to the information characteristic and it was analyzed the malaria occurrence distribution through the Manaus' neighbourhoods.

As to the ethical aspects, the explained and informed consent term was used, obeying the rules of research involving human beings.

Study area characterization

Lugar da Barra, as the city of Manaus - capital of the Amazonas - used to be called up to the end of the Eighteenth century, was only a settlement. In 1774, its population summed up only 220 inhabitants whose economic activity was limited to the extraction of Forest products, the so called "jungle drugs"(2). The economy evolved with the rubber exploitation and the Manaus Free Zone - MFZ (3).

Those processes generated changes in the city, when a large number of people "invaded" Manaus and came to settle into the peripheral areas. Consequently, the Manaus urban growth accelerated reaching nearly half all the population of the Amazonas State in 1980, which occurred without any structuring capable of absorbing and integrating this population into the social and economic process.

Many were the neighbourhoods that appeared following the implantation of the MFZ, most of them deprived of the essential means and town planning, "seeds of grave future problems for the city”(3-5).

The non-planed expansion caused an unbalance on the urban ecosystem, which added to the social economical situation of the inhabitants contributed to the decreasing quality of life, which is confirmed by the outbreak of disease $(1,6)$. Taking into account the fact of health being a sensitive indicator of the life and environment in which an individual is inserted. "Being healthy depends on the quality of the environment one has to live in”(7).

Several neighbourhoods appeared obeying the town planing profile for dwelling assemblages and " by occurring far apart from each other in a dispersed manner they gave way to the appearance of wide vacant spaces raising the cost of goods and services” (8). This brought about the arising of en- 
vironmental problems such as the contamination of the surface waters, caused by domestic sewage and other wastes from human activity (9). Those vacant spaces also facilitated the "disorderly" occupation by people trying to find a place to live that would be the closest possible to an area already possessing the beginnings of a living infrastructure, and by doing so hampering the structure and residents already in place.

From 1979 on, the city kept on expanding and also increasing the "invasions" of the central area with the improper occupation of the areas near the shorelines of the streams running through the city. This in fact brought about environmental problems worsened by the drainage of wastes and used waters, which are polluting these courses of water (9).

The occupation of Manaus occurred more pronouncedly towards the East Zone, and in second place, towards the North Zone. They were previously primary forested areas crosscut by streams. The natural habitat of some endemic species was invaded by the building of dwellings, which gave way for the outbreak of diseases on the human beings moving into those areas. Hence, malaria occurs coinciding with this occupation process in accordance to the degree of environment alteration and natural resources exploitation.

\section{RESULTS}

\section{Malaria in Manaus/Brazil}

"Despite the global effort employed for the eradication of malaria that lasted from 1965 to 1969 at the cost of hundreds of millions of dollars, malaria is still with us. In fact, malaria remains as the major tropical disease. Furthermore it is returning to the areas from where it had already been eradicated and its control is showing to become harder and harder to achieve on account of its ever-increasing resistance level to insecticides and drugs"(10).

Despite the fact malaria in the Amazonas had always presented high level of infection, there has been having increase in the city of Manaus, on the number of cases, mainly from the 1990s on (Figure 1). Even in 1946, the malaria was already considered the tropical disease of highest incidence, harmful to man and economy (11).

In the Figure 1 there is the annual cases of malaria in Manaus from 1962 to 1997, showing three epidemics picks in 1972, 1993 and 1997. The high incidence levels are accounted by the disease endemism itself, influenced by the continuous settling and natural resources exploitation due to "disorderly" social development $(12,13)$. 
From 1986 to 1997 (Table 1), it is noted malaria incidence doubled in 1990 - 1991, from 6386 cases to 13901 respectively. It is emphasised that from 1976 to 1987, there was no occurrence of malaria transmission cases within the Manaus urban area. In 1988, when transmission re-established itself, malaria incidence increased rapidly, with the more predominant parasite

Figure 1. Annual cases of malaria in Manaus from 1962 to 1997

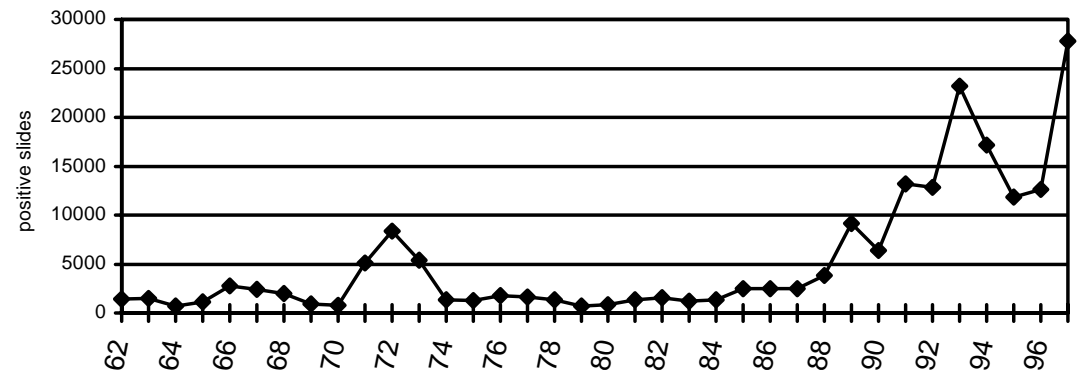

Source: FUNASA/IMT-AM

form brought about by the P. vivax.

1989, 1990, 1991, 1993, 1994 and 1997 were characterised for presenting lower incidence in the first semesters and the largest number of recorded cases of malaria occurring from July to September (Table 1).

Table 1. Total cases of malaria in Manaus per year and per month in the period from 1986 to 1997

\begin{tabular}{|c|c|c|c|c|c|c|c|c|c|c|c|c|}
\hline \multirow[t]{2}{*}{ Month } & \multicolumn{12}{|c|}{ YEARS } \\
\hline & 1986 & 1987 & 1988 & 1989 & 1990 & 1991 & 1992 & 1993 & 1994 & 1995 & 1996 & 1997 \\
\hline Jan & - & - & - & 426 & 623 & 540 & - & 1173 & 963 & 1469 & 645 & 2361 \\
\hline Feb & - & - & - & 499 & 523 & 422 & - & 1359 & 783 & 1127 & 484 & 937 \\
\hline Mar & - & - & - & 498 & 442 & 639 & - & 1664 & 845 & 1040 & 499 & 1057 \\
\hline Apr & - & - & - & 584 & 486 & 593 & - & 1159 & 796 & 660 & 451 & 1226 \\
\hline May & - & - & - & 596 & 543 & 558 & - & 1268 & 914 & 1009 & 536 & 1262 \\
\hline Jun & - & - & - & 372 & 565 & 292 & - & 2510 & 1437 & 839 & 719 & 1209 \\
\hline Jul & - & - & - & 666 & 954 & 1377 & - & 4483 & 1824 & 1164 & 1636 & 3020 \\
\hline Aug & - & - & - & 748 & 761 & 1747 & - & 3780 & 2469 & 1118 & 1898 & 3367 \\
\hline Sep & - & - & - & 1877 & 414 & - & - & 2712 & 2250 & 949 & 1166 & 5335 \\
\hline Oct & - & - & - & 1433 & 522 & - & - & 1363 & 1612 & 938 & 1543 & 3279 \\
\hline Nov & - & - & - & 896 & 225 & - & - & 845 & 1650 & 968 & 1177 & 1647 \\
\hline Dec & - & - & - & 694 & 325 & - & - & 873 & 1681 & 637 & 1345 & 3124 \\
\hline Total & 2463 & 2377 & 3482 & 9180 & 6383 & 13901 & 11712 & 23189 & 17224 & 11918 & 12099 & 27824 \\
\hline
\end{tabular}


Comparing these data with earlier studies (14), which reported malaria outbreaks usually starting in May, June or July, a shift can be observed of the starting time of the malaria outbreaks to July.

The autochthonous malaria record in Manaus in 1992 was 687 cases in January, decreased in the following months, and only increased in October and November. Malaria incidence was atypical that year being high in the end of the year, contributing for the large number of cases recorded in the beginning of 1993.

The year of 1995 was characterised by many oscillations of the incidence of malaria, yet it showed to be high throughout the year, whose lowest indexes were recorded in April, 660 cases; October, 938 cases, and December with 637 cases.

\section{DISCUSSION}

The distribution of the highest levels of malaria incidence occurred in the East Zone as compared to the other Manaus City zones. In this zone itself, the neighbourhood of Jorge Teixeira was the one recorded with the largest incidence; the second largest occurrence was in the North Zone, presenting the highest incidence in the neighbourhood of Santa Etelvina.

The higher occurrence in the East and North Zones can be accounted for by the way Manaus was settled, climatic environmental conditions, keeping in mind that several factors contribute for the maintenance of the malaric incidence (15). The Anopheles has domestic habits, yet they are not exclusive. The "malaria houses" conditions, shaded, humid, crude, untidy, are also found in the jungle itself, which favours the house breaking of the vector (14). We are talking about the feeding sources, the human blood, which the females fin easily. It is the law of the least the effort the better.

The different behavioural patterns of the Anopheles are in ecologically altered areas (16). According to the type of dwelling, and if the household is still very near the wilderness the mosquito that has diurnal and nocturnal habits, facilitates the man-vector contact, and thus, more possibility of transmission. Depending on the rhythm of occupation and urbanization process, the activity of the mosquito gets to being restricted to the nocturnal period. 
Together with these anopheline characteristics, we have the characteristic of the urban expansion itself, which followed the shoreline along the river, and then went back inland into the forest, north and east bound, - creating a semicircle of poor neighbourhoods (17). That, associated to the need of housing or even the cultural aspect of living close to water sources, should account for the dwelling near to or on the watercourses themselves.

As to 1993, studies from 1992 already pointed out for a large increase on malaria incidence (18), calling attention for a worsening of the endemicity both in the urban and rural zones. That period coincides with that of the settling of Jorge Teixeira (Easte Zone), a region that comprised large primary forest areas along with some private country sites. There were also several headwaters and the Igarapé do Mindu, the largest one of that area. Another coincidence was the settlement named João Paulo II (East Zone) late 1992 (18). From 1993 on, with the incoming of a larger number of people to that location, a high degree of environmental degradation followed by a high incidence of malaria is being observed.

The occupation of the Parque das Nações (Flores, North Zone) occurred in September/1995, and this locality alone accounted for $32 \%$ of all the cases of autochthonous malaria in the urban area of Manaus in 1997. That area had propitious conditions for the formation of Anopheles breeding sites, which were strengthened by the way the occupation was carried out and the great physiological alterations of the ecosystem by the damming of Igarapé do Bindá.

The number of low-income people inhabiting alongside and on the watercourses themselves is large (9). This has brought about a wide range of environmental problems. With an emphasis on high degree of degradation that is already noted on the shorelines and in the water quality in these streams, caused by the drainage of all types of wastes and sewage waters, in addition to the alterations on the local fauna and flora.

Although recent occupations have played a major role on the malaria incidence, over $70 \%$ of all cases in 1993 were recorded in areas that had been occupied for some time with a stable population, that is, areas where control was thought of as viable and executable with available methods. This demonstrates the degree of technical-administrative difficulties faced by the public services responsible for the malaria control in Manaus (19).

\section{CONCLUSION}


1. The malaria epidemiological situation present in Manaus in the period from 1986 to 1997, showed the occurrence of two epidemics, one in 1993 and another in 1997, having a larger number of cases caused by Plasmodium vivax occurred in all the studied years. A relation of the environmental, cultural, social and economical factors involving climatic characteristics, natural and reconstructed environment, and city urbanization, linked to the population vulnerability configure the favourable conditions for the maintenance of the Manaus incidence of malaria.

2. The analysis of the malaria cases diagnosed in Manaus shows that the areas most affected by the disease were in the East, with the highest incidence in Jorge Teixeira, followed by the North Zones, whose highest recorded number was in Santa Etelvina. This fact must be related to the environmental, climatic characteristics, and to the way the city was occupied, which in the last years occurred with a greater intensity in these zones. They are characterised by the "disorderly" occupations, which provided the ideal environmental conditions for the occurrence and reproduction of the Anopheles, which is a vector of this disease.

3. The malaria peaks that occurred in Manaus coincude wuth the periods of the appearance of some neighbourhoods, such as Tancredo Neves, Jorge Teixeira, João Paulo II in the East zone; Santa Etelvina, Monte das Oliveiras, Novo Israel in the North zone; and Parque das Nações, located in Flores, but is a lot closer to Cidade Nova (North zone).

4. Environmental alterations such as deforestation, alteration of the soil and of the watercourses. The population caused these alterations, not because they meant to cause this damage but because they had to provide themselves with the essential needs for their survival. This has made them interfere with the environment and many times have to build on risky areas such as on slopes, valley bottoms and too close to the untouched forest and become more vulnerable to the disease.

5. The accelerated urbanization process, which occurred in the city of Manaus, and the consequent incapacity to be followed up with the proper infrastructure and services, mainly sanitation is a factor that contributed for the malaria establishment and sustainability.

6. Environmental conditions also have an influence on the maintenance of the malaria vector, and the East zone was found to be where there had bee more anthropic interventions, characterised by alterations that favoured the appearance of new breeding sites for Anopheles. 
7. In fact, the increase on the intensity of malaria is related to the natural environmental matters. It can be stressed that this element by itself is not capable of determining the maintenance of the endemicity. Therefore, the way the city was expanded, urbanised and occupied, without the proper urbanenvironmental planning, which has a great influence on the incidence of the disease, must be added to the alterations produced by man on the natural environment •

\section{REFERENCES}

1. Alecrim WD. Ecossistema amazônico e o controle das endemias. Rev. Soc. Brasil. Med. Trop.1994; 2: 428-431, (supl. IV).

2. Monteiro, MY. Fundação de Manaus. 4.ed. aum. São Paulo, Metro Cúbico; 1994. 159p.

3. Freitas Pinto, ER. Como se produzem as Zonas Francas. Revista Seminário e Debates. Belém, NAEA/UFPA; 1987:19-38.

4. Andrade M. Manaus: ruas, fachadas e varandas. Manaus: Humberto Calderaro; 1984. $276 \mathrm{p}$.

5. Sabroza PC, Toledo LM, Osanai CH. A organização do espaço e os processo endêmico-epidêmicos. In: M. C. Leal, P. C. Sabroza; R. H. Rodríguez; P. M. Buss, orgs. Saúde, Ambiente e Desenvolvimento. São Paulo: Hucitec/ Rio de Janeiro: Abrasco; 1992: 57-77. vol. II.

6. Raggio A. Malária urbana. Divulgação em saúde para debate. Londrina; 1992. 8: 75.

7. Darnton-Hill I. El envejecimiento con salud y la calidad de la vida. Foro Mundial de la Salud. Organização Mundial de Saúde, Genebra, 1995; 16(4):381391.

8. Oliveira JA. As cidades amazônicas: a ilusão da busca. Boletim amazonense de geografia. 1995; 2: 23-41.

9. Santos SSM (coord.). Saneamento básico e problemas ambientais no município de Manaus. R. bras. Geogr., Rio de Janeiro, 1993; 55 (1/4): 15-60, jan./dez.

10. Litsios S. The tomorrow of malaria. Geneva: Pacific/ Ecotrends; 1996. 181p.

11. Batista D. O paludismo na Amazônia: contribuição à epidemiologia, à protozoologia e à clínica; estudo sobre a febre biliosa-hemoglobinúrica; síntese. Rio de Janeiro: Imprensa Nacional; 1946. 211 p.

12. Albuquerque MFPM. Urbanização, favelas, e endemias: a produção da filariose no Recife, Brasil. Cad. Saúde Públ. Rio de Janeiro, 1993; 9(4): 487-497, out/dez.

13. Organización Mundial de la Salud-OMS. Situación de Los Programas de Malaria en Las Americas. Informe XLII. XXIV Conferência Sanitária Panamericana XLVI Reunión Del Comité Regional. Washington, D.C.: Organización Panamericana de La Salud, Organización Mundial de La Salud. Septiembre; 1994. $113 \mathrm{p}$. 
14.. Scorzelli Junior A, Carreira da Silva A. O problema da malária em Manaus. Manaus: Imprensa Pública; 1939. 59 p.

15. Alecrim WD. Estudo clínico-epidemiológico da malária no Rio Ituxí - Amazonas. Dissertação de mestrado de Medicina Tropical. Universidade de Brasília; 1979.

16. Tadei WP, Santos JMM, Costa WLS, Scarpassa VM. Biologia de anofelinos amazônicos. XII. Ocorrência de espécies de Anopheles, dinâmica da transmissão e controle da malária na zona urbana de Ariquemes (Rondônia). Rev. Inst. Med. trop. São Paulo 1988; 30(3):221-251, maio-junho.

17. Araújo AV. Sociologia de Manaus: aspectos de sua aculturação. Temas de Sociologia. Manaus: Edições Fundação Cultural do Amazonas; 1974. Vol 2. p. 97-125.

18. Silva EB, Moura RCS, Silva VMFQ, Sampaio MZM, Sampaio LS, Teixeira FTV, et al. Estudo epidemiológico da malária no município de Manaus. Resumo. Anais do XXVIII Congresso da Sociedade Brasileira de Medicina Tropical, Belém; 1992, 23 a 27 de fevereiro. p. 8

19. Projeto para Controle da Malária em Manaus: proposta de atuação do município através da contração de serviços. Manaus (mimeo); 1994. 